\title{
Review of Life Cycle Sustainability Assessment and Potential for Its Adoption at an Automotive Company
}

\author{
Peter Tarne ${ }^{1,2, *}$, Marzia Traverso ${ }^{3}$ and Matthias Finkbeiner ${ }^{2}$ \\ 1 BMW Group, Department of Product Sustainability, Knorrstr. 147, 80788 München, Germany \\ 2 Technische Universität Berlin, Chair for Sustainable Engineering, Office Z1, Strasse des 17. Juni 135, \\ 10623 Berlin, Germany; matthias.finkbeiner@tu-berlin.de \\ 3 Sustainability Expert; marziatraverso@gmail.com \\ * Correspondence: peter.tarne@bmw.de; Tel.: +49-176-96649674
}

Academic Editor: Giuseppe Ioppolo

Received: 22 December 2016; Accepted: 19 April 2017; Published: 23 April 2017

\begin{abstract}
The aim of this paper is to guide the next steps of a $\mathrm{PhD}$ thesis through a structured review of the state of the art and implementation of Life Cycle Sustainability Assessment (LCSA), and to identify challenges and potentials for its adoption at an automotive company. First, the structured literature review was conducted on LCSA to screen the current methodological and practical implementations and to identify the main research needs in the field. Second, a research on the current status of LCSA within the automotive industry was carried out by means of investigation of published sources of 15 Original Equipment Manufacturers (OEM). By combining the results of both steps and consulting with decision makers, the challenges and potential for adopting LCSA at an automotive company were identified. The main challenges for adoption of LCSA were found to be: (1) the consistent execution of the three life cycle based assessment methods; (2) the comparatively low maturity of Social Life Cycle Assessment (S-LCA); and (3) the adequate presentation and interpretation of results. Next steps towards implementation would be a case study to gather experience on the combined execution of the three life cycle based assessments at an automotive company. Furthermore, it should be determined what the needs of decision makers at an automotive company are regarding the aggregation and interpretation of environmental, social, and economic impacts.
\end{abstract}

Keywords: LCSA; structured literature review; product sustainability assessment

\section{Introduction}

Products influence all three dimensions of sustainability, i.e., economy, environment, and society. Their manufacturing and often their usage is linked to resource use, land use, and pollution of the environmental media. Furthermore, products have an effect on both economy and society because their life cycle, i.e., manufacturing, use, and disposal, give rise to employment and contribute to value generation. In addition, products satisfy the needs of customers. When assessing sustainability, how sustainability is understood has a decisive impact on the mode of assessment. There are two fundamentally different approaches to assessing sustainability, the first one is viewing the three dimensions of sustainability partially independent from one another while the second one understands the three dimensions to be integrated and thus not independently manageable $[1,2]$. Product sustainability assessment should take the impacts over the entire product's life cycle into account [3].

The most accepted framework and life cycle based approach for assessing a product's impacts on all three sustainability dimensions in an integrated way is Life Cycle Sustainability Assessment (LCSA) [3-7]. It is currently regarded as the only viable framework for comprehensive sustainability assessment of products $[8,9]$. It can be understood as the evaluation of the combined positive 
and negative effects of a product over its entire life cycle on the three dimensions of sustainability. This comprehensive assessment can be expressed by the following conceptual formula (1):

$$
\mathrm{LCSA}=\mathrm{LCA}+\mathrm{S}-\mathrm{LCA}+\mathrm{LCC}
$$

where LCA (Life Cycle Assessment) denotes the conventional environmental life cycle assessment [10,11], S-LCA (Social Life Cycle Assessment) represents the assessment of positive and negative social impacts along the product life cycle [12,13]., and LCC stands for Life Cycle Costing, the assessment of economic impacts along product life cycle $[14,15]$. The interpretation of LCC results can express sheer costs or more broadly impacts (e.g., change of wealth of economic well-being of stakeholders). This research adheres to the economic interpretation as the improvement of sustainability in the sense of the Brundtland report [16] is captured by the combined LCSA framework. Thus far, no structured literature review has been conducted on the state of the art of LCSA. Sala et al. [17] is the most complete analysis of the state of the art of the LCSA against ontological, epistemological and methodological aspects of the ongoing scientific debate on sustainability but no structured review of the current published references on LCSA has been made even in this publication.

The automotive industry recognizes the need for improvement when it comes to the sustainability impacts of the transport sector. To efficiently and effectively work on the improvement of sustainability impacts, their quantification is an important step. Adopting LCSA within the automotive industry would enable a comprehensive approach on measuring and managing product sustainability. An overview of the state of the art of LCSA and its implications for adopting it at an automotive company is instrumental for setting the implementation effort off in the right direction. Thus far, no analysis of the state of the art of LCSA in relation to the automotive sector has been carried out.

The aim of this paper is to collect and organize the main references on LCSA in a structured way, and to build a complete picture of the theoretical and practical implementation of this methodology in the automotive sector. Afterwards this picture was used to identify the main needs for further research in the field of LCSA. For guiding specific research efforts towards the implementation, the challenges and potential for LCSA at an automotive company were identified. These results can support further researchers in this field to easily identify further steps needed in the adoption of LCSA at an automotive company. In any case, it represents the first step of a PhD thesis on LCSA at an automotive company. The necessity to draw a structured review that is easy to follow, generic and specific for the automotive sector is led by the need to communicate the results to experts and non-experts of the sustainability field. The PhD thesis has been funded by the BMW Group in cooperation with TU Berlin which is the first time a research on the operationalization of LCSA has been founded by an automotive company.

The research was divided into three steps:

(A) Structured literature review on LCSA to identify the main research needs.

(B) Identification of currently communicated life cycle based product sustainability assessment of automotive companies to establish a benchmark.

(C) Mirroring of retrieved results to decision makers and identification of challenges and potential of LCSA at an automotive company.

\section{Materials and Methods}

The first step consisted of a structured literature review on the state of the art of LCSA in general (cf. Step A in Section 1). Here, only literature that assessed at least two of the three sustainability pillars along the product life cycle was considered. In considering those literature references, differences were made according to methodologies for interpreting the LCSA results, e.g., Multi-Criteria Decision Analysis (MCDA). This does not mean that in the review an exhaustive state of the art of MCDA as well but instead that only those references where the MCDA has been applied to interpret LCSA results were included and discussed. The second step turned toward the automotive industry and identified the status of LCSA at the top Original Equipment Manufacturers (OEM) in the world (cf. Step B in 
Section 1). By taking the results of both steps into account and consulting with decision makers, the challenges and potential for operationalization of LCSA at an automotive company were derived (cf. Step C in Section 1).

\subsection{Structured Literature Review of LCSA Research Field}

For the first step of this research, a structured literature review approach was chosen to determine the state of the art of LCSA. Structured literature reviews provide collective insight into a field and enable researchers to develop a reliable knowledge base [18]. As it is a structured method, it reduces researcher bias and, ideally, yields reproducible results [19].

The steps of the literature review were as follows [18-22]:

(1) Formulation of review protocol

(2) Formulation of research question

(3) Formulation of inclusion and exclusion criteria

(4) Search for literature

(5) Evaluation of literature

\subsubsection{Review Protocol}

A protocol has to be set up that documents the undertaken steps and criteria [18,23]. Table 1 shows the review protocol of the conducted literature review.

Table 1. Review protocol.

\begin{tabular}{cl}
\hline \multirow{2}{*}{ Review question } & $\begin{array}{l}\text { "What are the thematic fields of research regarding LCSA and what are the identified } \\
\text { needs for future research?" }\end{array}$ \\
\hline \multirow{3}{*}{ Inclusion criteria } & $\begin{array}{l}\text { Title: “Life Cycle Sustainability Assessment" or more than one } \\
\text { sustainability dimension }\end{array}$ \\
\cline { 2 - 2 } & $\begin{array}{l}\text { Abstract and full text: at least two sustainability dimensions and when it dealt with } \\
\text { the method }\end{array}$ \\
\hline \multirow{2}{*}{ Exclusion criteria } & $\begin{array}{l}\text { Book reviews; non-English publications; addressing of just one } \\
\text { sustainability dimension }\end{array}$ \\
\hline \multirow{3}{*}{ Literature search } & $\begin{array}{l}\text { Sources: specialist, scientific online platforms (ScienceDirect, WileyOnline, } \\
\text { SpringerLink, MDPI), citations in identified literature }\end{array}$ \\
\cline { 2 - 2 } & $\begin{array}{l}\text { Search phrase: “Life Cycle Sustainability Assessment" in title and abstract with no } \\
\text { limitation to publication year }\end{array}$ \\
\hline \multirow{2}{*}{ Evaluation } & $\begin{array}{l}\text { Following information were extracted from the publication and transferred into an } \\
\text { excel document: specifications of publication, scope of publication, results } \\
\text { of publication }\end{array}$ \\
\hline
\end{tabular}

\subsubsection{Research Question}

The following research question guided the structured literature review: "What are the thematic fields of research regarding LCSA and what are the identified needs for future research?" In this first part no particular reference to the automotive sector has been made to catch and identify all scientific references related to the LCSA. For the same reason mentioned above, the research questions have been formulate quite generic and wide to collect as much inputs as possible.

\subsubsection{Inclusion and Exclusion Criteria}

(A) Inclusion Criteria

a. Title: When the phrase "Life Cycle Sustainability Assessment" was found; when more than one dimension of sustainability was addressed; when dimensions were not clear but "sustainability" was mentioned. 
b. Abstract: When at least two sustainability dimensions were addressed and when it applied, evaluated, developed, or advanced a method.

c. Full text: When at least two sustainability dimensions were addressed and when it applied, evaluated, developed, or advanced a method.

(B) Exclusion Criteria
a. Book reviews
b. Non-English publications
c. Addressing of just one sustainability dimension

The identified literature was then analyzed in regards to the main topics that they dealt with and were grouped by the authors according to major overarching thematic fields. The thematic fields were derived by the authors and were guided by the topics that emerged as well as the motivation to limit the number of fields. As the aim was to generate a broad overview that is also comprehensible for non-experts of LCSA it was decided to not differentiate between too many thematic fields.

\subsubsection{Search for literature}

To define the search for literature, the sources (A) and keywords (B) had to be specified.

(A) Sources

First, the sources for the literature search were defined. As several approaches to identifying relevant literature are recommended $[18,20]$, a specialist was asked about the main sources for the respective question [21]. This yielded the International Journal of Life Cycle Assessment, the Journal of Cleaner Production, the Journal of Industrial Ecology and the open access journal Sustainability as the most relevant sources.

This seemed reasonable as the literature review of Mattioda et al. [24] on S-LCA also found those four journals to contain the majority $(68 \%)$ of the relevant publications. To extend the scope, the search was conducted on the scientific portals that host the respective journals, i.e., SpringerLink (International Journal of Life Cycle Assessment), WileyOnline (Journal of Industrial Ecology), ScienceDirect (Journal of Cleaner Production), and MDPI (Sustainability).

Furthermore, cross checking and searching of citations in the identified literature was applied in this research to identify relevant publications not included in the initial sources $[20,25]$.

(B) Keywords

Initially, the keywords "life cycle", "sustainability", and "assessment" were defined as Life Cycle Sustainability Assessment and its status in the automotive industry was chosen as the object of research. As the search with this set of keywords yielded more than 10,000 results, a more stringent search term was defined to achieve a more manageable amount of hits. However, even partially limiting the search term by searching for instance for "life cycle" and "sustainability assessment" yielded hits way in excess of 10,000. Eventually, the exact phrase was therefore limited to "Life Cycle Sustainability Assessment" which was searched for in titles and abstracts with no restriction to publication year. The search was done in July 2015. This resulted in 274 initial hits. Figure 1 shows the process of the literature search and subsequent identification of relevant publications. 


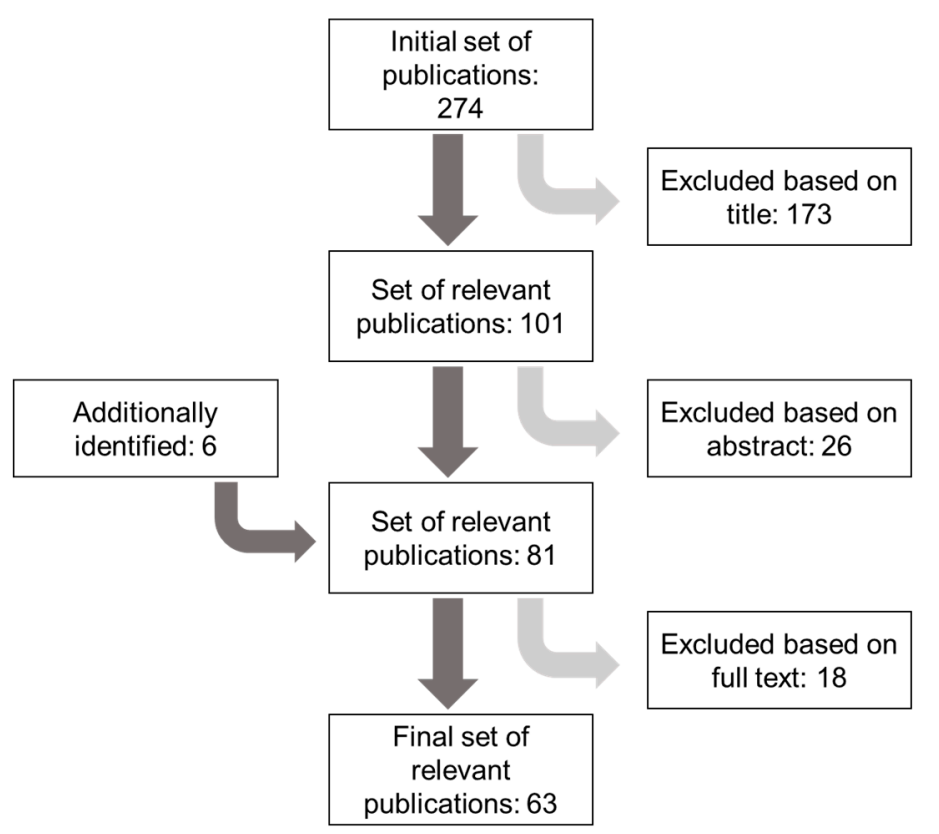

Figure 1. Schematic illustration of the literature search and selection process.

According to Miemczyk et al. [26], the titles of the identified publications were then checked against the inclusion/exclusion criteria (cf. Table 1), which diminished the pool to 101 relevant items. In the next step, the abstracts were evaluated regarding whether they fit the inclusion/exclusion criteria. This resulted in a total of 81 relevant publications for the evaluation. After full-text analysis, another 18 publications were excluded, leaving a set of 63 relevant publications for the state of the art analysis.

\subsubsection{Evaluation}

Following the example of Zimmer et al. [25], classification categories were defined for a systematic evaluation of the identified body of relevant literature.

(A) Specifications of Publication

The first classification category serves the purpose of capturing the basic parameters of the publication. Thus, year of publication, type of publication (journal article, conference report, book chapter, etc.), and name of source were chosen for this category.

(B) Scope of Publication

In order to categorize the publications pertaining more to their content and scope, the following parameters were chosen for this category:

- Type of study (empirical, theoretical, or both)

Following Wacker [27] who divide papers into "analytical" and "empirical", the types of study were divided into "theoretical", meaning the development of a method or framework without testing it or structuring/summarizing of existing approaches, indicators, views, etc. "Empirical" denotes a publication that employs a case study without seeking major adjustments to the method applied. The classification "both" was used for publications that either developed a new method or advanced an existing one and tested this method with a case study.

- Industry sector 
In the case a publication or case study was directed at, or carried out in, a specific industry sector, this was recorded here.

\section{- $\quad$ Addressed sustainability dimension}

It was recorded which sustainability dimensions were addressed in a publication. All studies that addressed just one dimension were excluded from the research.

- $\quad$ Type of case study

Case studies were categorized into "full case study" or "numerical example" depending on whether they collected real data or whether they tested a method using fictional values.

\subsection{Evaluation of Current Status in the Automotive Industry}

The second step of the research was conducted independently of the structured literature review on LCSA. As the initial search for papers on LCSA in the automotive industry basically just yielded the paper by Traverso et al. [28], the publications (mainly sustainability reports and product related information) of the 15 largest automobile manufacturers by production volume were analyzed in order to get an overview of the current status of Life Cycle Sustainability Assessment in the automotive industry.

\subsection{Implications for Application at an Automotive Company}

In order to identify the most pressing challenges out of the ones identified by the two previous research steps (Sections 2.1 and 2.2) for the adoption of LCSA, decision makers at an automotive company were consulted. The consulting process was carried out with 12 decision makers who were at least at the level of department head. They were first presented with the findings of the two previous research steps and were asked in a semi-structured interview whether they agreed with the identified challenges and potentials for adoption of LCSA within an automotive company. In a second step, they were asked about their expectations towards an operational LCSA framework. The interviews were conducted in person.

\section{Results and Discussion}

\subsection{State of the Art of LCSA}

The drastic reduction in initial hits from way over 10,000 to 274 after limiting the literature search string indicates a high "noise", meaning not pertinent literature, when searching for publications related to life cycle sustainability assessments. This is not surprising as the individual key words tap into separate extensive fields of research which is why the search had to be limited in the first place. The comparatively low amount of initial hits with the limited search string indicates that the specific field of Life Cycle Sustainability Assessment is still in development. This indication is substantiated by the further findings in this research. The final set of analyzed publications of 63 compares to other structured literature reviews $[20,26,29]$.

A detailed overview of the analyzed publications and their classification along with a list of the initial hits can be found in the supplementary material to this article.

\subsubsection{Bibliometric Results}

In the following, bibliometric evaluations of the set of examined publications are presented visualizing some characteristics and developments in the field of LCSA research. Figure 2 shows the distribution of publications by year. 


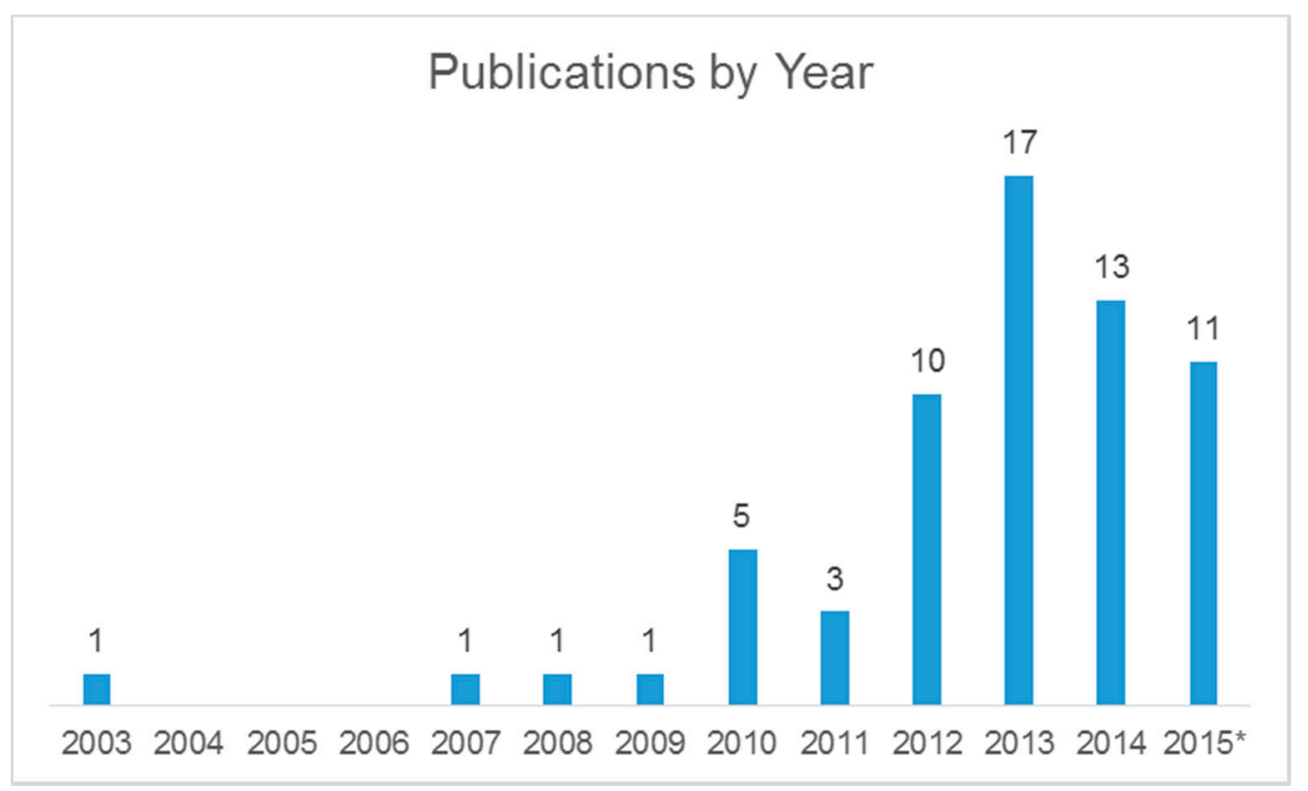

Figure 2. Distribution of publications by year. * The review was conducted in July 2015, thus not all publications in 2015 could be considered in this research.

It can be clearly seen that the majority of publications appeared after 2011. An increasing trend can be assumed as the figure for 2015 only includes publications up until July 2015 when the data for this research were gathered. The fact that most of the LCSA related research has been published after 2011 when the UNEP/SETAC guidelines were published re-affirmed the need for this research. The peak in publications in 2013 can be explained be the special issue on Life Cycle Sustainability Assessment by The International Journal of Life Cycle Assessment out of which eight papers were included in this review. Table 2 displays the publications by source.

Table 2. Distribution of publication by source/journal. All sources that contributed just one publication were subsumed under "Rest".

\begin{tabular}{lc}
\hline Name of Journal & No. of Publications \\
\hline The International Journal of LCA & 21 \\
Sustainability & 10 \\
Journal of Cleaner Production & 5 \\
Journal of Industrial Ecology & 4 \\
Applied Energy & 2 \\
Journal of Remanufacturing & 2 \\
Procedia CIRP & 2 \\
Rest & 17 \\
Total & $\mathbf{6 3}$ \\
\hline
\end{tabular}

It is evident that The International Journal of Life Cycle Assessment is the dominating medium in the field of LCSA, followed by the online journal Sustainability. The rather large share of sources under "Rest" indicates that the chosen research method enabled the identification of relevant publications that were not contained in the initial sources of the search thus proving the viability of the chosen method. Figure 3 shows the characteristics of the examined set of publications in regards to the type of study. 


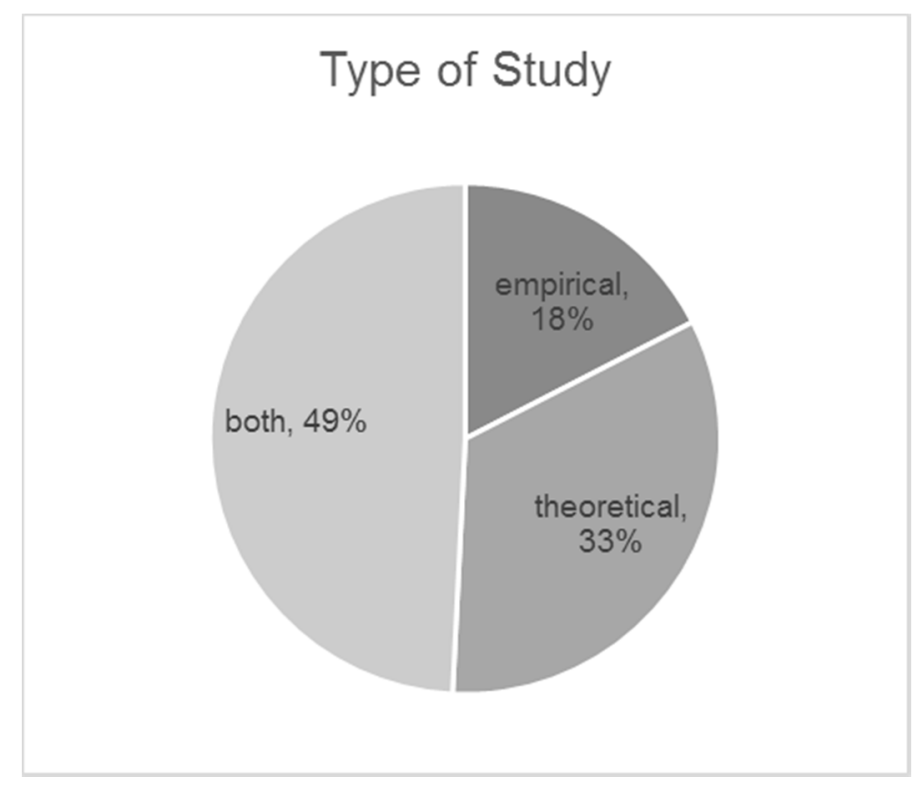

Figure 3. Publications by type of study.

As can be seen in Figure 3, 52 of the examined publications had theoretical elements (mostly development of assessment methods), whereas 42 had empirical elements (mostly case studies). As the group of studies that combine empirical and theoretical elements is mainly comprised of method developments that are subsequently tested by case studies it can be summarized that the field of analyzed literature leans more strongly towards method development rather than gathering empirical evidence using existing methods and frameworks. This is underpinned by only 11 publications containing pure case studies. This distribution of theoretical versus empirical studies shows characteristics of a nascent to intermediate state regarding the maturity of the field of research [30]. When looking at the numbers of sustainability dimensions addressed, $80 \%$ of publications addressed all three dimensions while $20 \%$ only addressed two sustainability dimensions. Publications that addressed just one dimension were excluded from this research and were thus not present in the review.

The distribution of industry sectors that were dealt with in the examined publications is presented in Table 3.

Table 3. Distribution of industry sectors that were addressed in the examined publications. Twenty publications did not explicitly address a specific industry sector.

\begin{tabular}{lc}
\hline Industry Sector & No. of Publications \\
\hline- & 20 \\
Building & 8 \\
Automotive & 7 \\
Energy & 6 \\
Fuels & 5 \\
Waste Management & 4 \\
Agriculture & 3 \\
Electronics & 2 \\
Other & 8 \\
Total & $\mathbf{6 3}$ \\
\hline
\end{tabular}

Out of the analyzed publications, 20 did not specifically address an industry sector (see Table 3). That makes for a consistent picture of the examined set as 21 publications used only a theoretical approach (cf. Figure 3) not requiring a link into practice. The most prominent industry sectors were 
building, automotive, energy, and waste management. These findings underpin that the automotive industry is in the focus when it comes to the sustainability of products. When looking at the countries of origin of the publications, the field was led by Germany (21\%) followed by Italy (16\%), USA (13\%) and the UK $(11 \%)$.

\subsubsection{Classification of Literature by Thematic Fields}

The thematic clustering of the research field was not straightforward as the set of examined publications posed a heterogeneous group of publications with no clear "mainstream" discernible or clear delineations between different research foci. This in itself already constitutes a major finding of this review. Nonetheless, it was found that the field could be clustered into four thematic fields: "Framework", "Method Integration", "Case Studies", and "Alternative Assessment Methods". The thematic field "Framework" comprised all research papers that dealt with the principle logic and further development of the framework LCSA rather than singular methods. Papers in the field of "Method Integration" were dealing with the integration of methods, meaning that parts or elements of the higher-level framework were extended, changed, or added. The thematic field "Case Studies" was made up by publications that mainly carried out case studies for LCSA. The last field "Alternative Assessment Methods" denotes the collection of papers that were developing their own assessment method by either incorporating parts of or totally independent from the LCSA framework. Table 4 shows an overview of the thematic fields and the respective publications.

Table 4. Overview of thematic fields of LCSA literature and the according authors.

\begin{tabular}{|c|c|c|}
\hline Thematic Field & Subcluster & Authors \\
\hline Framework & & $\begin{array}{l}\text { Klöpffer (2003), Klöpffer (2008), Heijungs et al. (2009), Finkbeiner et al. (2010), } \\
\text { Heijungs et al. (2010), Guinée et al. (2011), UNEP (2011), Zamagni (2012), Cinelli et al. } \\
\text { (2013), Jørgensen et al. (2013), Sala et al. (2013), Sala et al. (2013), Zamagni et al. (2013), } \\
\text { Hoogmartens et al. (2014), Klöpffer and Grahl (2014), Keller et al. (2015), } \\
\text { Neugebauer et al. (2015), Traverso et al. (2015) }\end{array}$ \\
\hline \multirow{3}{*}{$\begin{array}{c}\text { Method } \\
\text { Integration }\end{array}$} & LCSA Steps & $\begin{array}{l}\text { Foolmaun and Ramjeawon (2013), Foolmaun and Ramjeeawon (2013), } \\
\text { Hu et al. (2013),Pesonen and Horn (2013), Vinyes et al. (2013), Stefanova et al. (2014), } \\
\text { Souza et al. (2015) }\end{array}$ \\
\hline & $\begin{array}{c}\text { Multi-Criteria } \\
\text { Decision Analysis }\end{array}$ & $\begin{array}{l}\text { Halog and Manik (2011), Ghadimi et al. (2012), Manzardo et al. (2012), Bachmann (2013), } \\
\text { Ostermeyer et al. (2013), Wang and Chan (2013), Buchert et al. (2015), Ren et al. (2015) }\end{array}$ \\
\hline & $\begin{array}{l}\text { Multi-Regional } \\
\text { Input-Output Analysis }\end{array}$ & Kucukvar and Tatari (2013), Kucukvar et al. (2014), Onat et al. (2014), Onat et al. (2014) \\
\hline Case Studies & & $\begin{array}{l}\text { Brandão et al. (2010), Schau et al. (2012), Traverso et al. (2012a), Traverso et al. (2012b), } \\
\text { Valdivia et al. (2013), Lu et al. (2014), Martínez-Blanco et al. (2014), Minne and } \\
\text { Crittenden (2015), Yu and Halog (2015) }\end{array}$ \\
\hline $\begin{array}{l}\text { Alternative } \\
\text { Assessment } \\
\text { Methods }\end{array}$ & & $\begin{array}{l}\text { Zhou et al. (2007), Azapagic and Stichnothe (2010), Moriizumi et al. (2010), Jeswani and } \\
\text { Azapagic (2012), Nzila et al. (2012), Schulz et al. (2012), Stamford and Azapagic (2012), } \\
\text { Luthe et al. (2013), Tugnoli et al. (2013), Ingwersen et al. (2014), Mjörnell et al. (2014), } \\
\text { Shuaib et al. (2014), Stamford and Azapagic (2014), Torquati et al. (2014), } \\
\text { Dewulf et al. (2015), Hirschberg and Burgherr (2015), Li et al. (2015) }\end{array}$ \\
\hline
\end{tabular}

There are different understandings of how to approach product sustainability in general as becomes evident in the different understandings on how to develop a framework, and to Life Cycle Sustainability Assessment in particular as there were plethora of issues addressed and even more alternative assessment methods developed.

Framework

Publications sorted into this category dealt with the principle logic and further development of the framework LCSA rather than singular methods. In this review paper, the acronym LCSA stands for the Life Cycle Sustainability Assessment framework as defined by Klöpffer [4,5] and Finkbeiner et al. [6].

The foundations for the LCSA framework as a complementary application of the life cycle assessment methods LCA, S-LCA, and LCC were laid by Klöpffer and Finkbeiner. They gave two options of how this could be achieved: either by carrying out those three separate assessments with 
the same system boundaries or applying them as three different impact assessments to the same life cycle inventory [5]. In the quasi-guidelines by UNEP/SETAC [3], it was added that, in addition to the same system boundaries of all three methods within LCSA, the same temporal horizons are also to be considered.

The first overview of the status quo of the LCSA techniques LCA, LCC, and S-LCA were given by Finkbeiner et al. [3,7]. They also adopted Maslow's pyramid of needs to reflect the hierarchy of sustainability assessment approaches showing LCSA on top and thus as the most sophisticated product sustainability assessment available. Furthermore, they introduced two presentation tools for LCSA results: the Life Cycle Sustainability Triangle and the Life Cycle Sustainability Dashboard [7,31,32]. Zamagni [9] affirmed that LCSA is the state of the art of life cycle based sustainability assessment.

Sala et al. $[17,33]$ developed a framework in order to structure the field of sustainability science according to the scientific and social paradigm. Then they conducted a meta-review of papers on sustainability assessments in order to check whether they could be integrated in the freshly developed sustainability science framework. In their evaluation, they compared the LCSA framework by Klöpffer and the Life Cycle Sustainability Analysis framework by Guinée and colleagues against their sustainability assessment. Both frameworks were considered potentially fit to work as sustainability assessment method, but the framework of Guinée et al. was seen as further along although it still missed translation into operation $[17,33]$. Therefore, their framework was not further considered for the following steps of this research.

Hoogmartens et al. [34] included Cost-Benefit-Analysis (CBA) in their status report on LCSA as they compared and discussed LCA, LCC, S-LCA, and CBA in regards to the assessment of sustainability resulting in an illustrative framework to show differences and interactions. Environmental LCC was regarded as "pure LCC", full environmental LCC as LCC with monetization of environmental impacts.

In 2014, Klöpffer and Grahl noted that no substantial development on LCSA had taken place and that LCSA could be realized by taking several routes [35]:

(1) LCC + S-LCA as additional impact categories for a life cycle inventory (LCI) of an LCA

(2) Eco-efficiency + S-LCA

(3) LCA + socioeconomic analysis

However, there also exists doubt that a combination of LCA, S-LCA, and LCC would lead to a more comprehensive sustainability assessment. Jørgensen et al. [36] analyzed whether the proposed LCSA could actually assess the effects on sustainability as defined in the Brundtland report. They found that LCA and S-LCA are necessary (even though further development towards assessment of poverty is needed) but LCC is not necessarily an integral part [36].

An extension to the LCSA framework was introduced by Keller et al. [37]. In order to take barriers to implementation into account, thus providing a better basis for decision support, they proposed four elements of evaluation: technology, environment, economy, and social, with only the environmental indicators derived from a clearly life cycle based tool (LCA).

Aiming at facilitating the application of LCSA, Neugebauer et al. [38] proposed a tiered structure to LCSA, depending on the level of barriers to operationalization. Tier 1 provided a set of midpoint indicators that were rather easy to assess and interpret, whereas Tier 3 suggested a comprehensive approach with an extended list of indicators and impact categories calling for a higher effort in execution but yielded a more detailed result [38].

As main future research needs the publications mainly identified the challenges that come with combining three method into one framework consistently [9]. Firstly, the methods displayed different degrees of maturity with especially S-LCA having the challenge of affluence of indicators and difficulty of quantification and relation to product $[7,35]$. Secondly, the consistency requirement calling for same system boundaries for all methods were considered to demand some further work as it was not clear whether this was always feasible or even conceptually correct [9]. Thirdly, the weighting and 
aggregation within LCSA should be addressed as this would enable researchers/users to arrive at a combined result more clearly able to support decision makers [7].

Other prominent fields for future research were the communication of LCSA results $[37,39,40]$ and data availability $[7,37]$.

\section{Method Integration}

Publications of this category dealt with the integration of methods, meaning that parts or elements of the higher-level framework were extended, changed, or added. The field of method integration could be further divided into publications focusing on LCSA Steps, the application of Multi-Criteria Decision Analysis, and the application of Multi-Regional Input-Output Analysis.

LCSA Steps

Further structuring of the goal and scope phase of LCSA in order to make it more operational is suggested by Hu et al. [41] and Stefanova et al. [42]. This could be achieved by either introducing questions which answers will lead to goal and scope definition [41] or by defining the phase top-down. The latter was suggested by first defining macro-goals followed by a technology map that comprises all possible routes to achieve those goals. Finally, the establishment of a context determines what routes can be taken and what routes have to be excluded, thus setting the scope of the assessment [42].

Following the idea of simplification, the introduction of a Strengths-Weaknesses-OpportunitiesThreats (SWOT) matrix as a streamlined LCSA approach that incorporates all three dimensions in a concise manner that is easily to communicate was examined by Pesonen and Horn [43].

Turning to the impact assessment phase, several researchers proposed a simplified impact assessment when comparing alternative scenarios by setting the best performing option in a respective category as $100 \%$ and putting the other options in relation [44-46]. The missing consensus on impact pathways motivated Souza et al. [47] to develop a method to define impact categories and impact pathways for the social and economic dimension of LCSA by stakeholder engagement. They derived causal maps from the subjective feedback of stakeholders which resulted in familiar impact categories but also new ones, especially for social: digital inclusion was additionally identified, whereas child labor and collective bargaining were not considered relevant [47].

Future research needs identified were the weighting and measuring of social impacts along with the definition impact categories in economic dimension [44,45], and the conduction of further case studies [41,47].

\section{Multi-Criteria Decision Analysis}

Several authors chose to integrate multi-criteria decision analysis (MCDA) in order to be able to combine different indicators into one aggregated result, deriving weights for the respective indicators, and even translate qualitative information into quantitative metrics [48-52]. In order to determine weights, researchers usually applied fuzzy evaluation methods, the Analytical Hierarchy Process (AHP) or a combination of those to translate qualitative evaluations of experts into metrics [48-51,53]. Additional methods like TOPSIS or VIKOR were then used to either determine distance to target [50] or the best alternative [51]. Ostermeyer et al. [54] dealt with the multi-criteria approach using Pareto optimization together with the application of LCC + LCA and defined more than 700 scenarios out of which the preferred option was identified using the Pareto optimal approach. Bachmann [55] derived suggestions for developing LCSA by comparing the external costs assessment and the MCDA within the NEEDS project concluding that both overlap except regarding social indicators and a consequential approach would be preferable when modeling LCSA.

Multi-criteria decision models were also used for a method that was developed to consider sustainability aspects early in the design process by integrating LCSA, engineering design 
processes, and multi-criteria assessment. The combination resulted in a decision-tree that depicted several design solutions and their impacts which was then analyzed using multi-criteria assessment in order to determine the preferable option [52].

In the field of multi-criteria decision models within LCSA, the definition and choice of suitable criteria in LCC, LCA, and S-LCA was desired for future research $[48,52,55]$. Furthermore, the integration of dynamic relations between evaluation criteria and other dynamic influences like energy mixes, costs, and discount rates should be looked at [50,54].

Multi-Regional Input-Output Analysis

Several publications made use of extended multi-regional input-output (MRIO) analyses to determine the sustainability impacts of the US building sector $[56,57]$ and different automotive drive-trains [58]. The initial method was developed by Kucukvar and Tatari [56] who used supply and use tables from the U.S. Bureau of Economic Analysis to model supply relationships between industry sectors and therefore simulate a supply chain. Kucukvar et al. [59] expanded the method by Kucukvar and Tatari [56] by using a multi-criteria decision model to determine the ideal alternative under given weights for sustainability dimensions.

Areas for improvement by future research would be a better disaggregation of construction sector in input-output models [56] as well as further development of MRIO tables regarding the granularity of the models and development of dynamic models $[57,58]$.

\section{Alternative Assessment Methods}

A considerable proportion of the examined publications were developing their own assessment method either incorporating parts of or totally independent from the LCSA framework. Some authors took LCSA elements and either developed a simplified tool that allows quick assessment of wastewater treatment options based on LCA and LCC [60] or combined LCA and economic indicators to assess biogas production options in Kenya [61]. Other partial integration was done by Luthe et al. [62] who developed a tool that integrates LCA, S-LCA, and economical aspects into product design, while Mjörnell et al. [63] claimed to integrate all three LCSA components into their sustainability assessment, even though they chose indicators from the S2020 Knowledge Matrix instead of established S-LCA sources.

Most of the publications, however, developed their own assessment method, totally independent from the LCSA framework. A rather elaborate assessment method was introduced by Stamford and Azapagic [64] who used 43 indicators grouped into sustainability sections (techno-economic, environmental, social) to assess possible future energy mixes in the UK. They followed up their assessment with a revised method, employing 16 indicators that followed LCA for environmental impacts but own deliberations regarding economic and social impacts to identify the most sustainable energy mix for the UK in 2070 [65]. Similarly, the assessment of primary energy carriers was the focus of the Integrated Sustainability Assessment Framework (ISAF) in which 15 indicators for four sustainability dimensions (adding "technology" to the three conventional ones) were suggested [66]. Energy sources were also assessed by Hirschberg and Burgherr [67] who based their indicators on the NEEDS framework. They resorted to LCA for the environmental dimension, expert judgment for the social dimension, for which the indicators health and security were chosen and capital investment plus fuel costs for the economic dimension. Aggregation of results was achieved by calculation of external costs or through MCDA [67]. In contrast, Moriizumi et al. [68] used a life cycle based assessment of different mangrove management options using just one indicator per sustainability dimension and, similarly, Zhou et al. [69] conducted their assessment based on four indicators that covered environmental and economic impacts.

Two publications suggested the inclusion of already existing methods and indices. Ingwersen et al. [70] proposed to include integrated metrics, such as Ecological Footprint, Green Net Value Added, Fisher Information into sustainability assessment as they can address additional 
aspects such as carrying capacity (Ecological Footprint) and were already established. Li et al. [71] on the other hand developed a sustainability assessment model by combining LCA, full cost accounting (FCA), health risk assessment, and AHP. Another two publications combined existing LCA studies on biofuels with information from different sources on investment and operation costs for different biofuel plants. A qualitative appraisal of social impacts was done additionally to cover all three dimensions. No combined presentation of results was given [72,73].

The main research needs in this rather diverse set of publications were identified to be more testing of the developed methods $[63,64,66]$, refinement and ranking of indicators $[61,70]$, and the incorporation of input-output analysis [60].

\section{Case Studies}

The last of the four identified main fields in the analyzed set of publications was composed of case studies that were applying LCSA methods in order to test their applicability and gain more insights into the implications of the results gained by applying those methods.

The most straightforward application of LCSA was undertaken by Traverso et al. [31,32], Schau et al. [74], and Valdivia et al. [40] who applied the framework to floor coverings, photovoltaic modules, remanufacturing of automobile alternators, and several types of marble, respectively. Traverso et al. [31] introduced the Dashboard of Sustainability as communication tool for assessment results. Furthermore, LCSA was applied by Lu et al. [75] to assess two recycling routes (material recovery or component reuse) of mobile phones in the formal and informal recycling sector in China and by Yu and Halog [76] who assessed a PV array in Australia using LCSA but using a rather basic qualitative approach for S-LCA. They interpreted secondary data (reports, websites, and literature) from main supply chain actors in a color-coded matrix.

A case study using LCSA framework with special focus on S-LCA on mineral and compost fertilizers was conducted by Martínez-Blanco et al. [77] who used data from LCA databases (environmental impacts), LCC (purchase price), and S-LCA (Social Hotspot Database) to assess the sustainability impacts of fertilizers. Two other case studies used a slimmed down approach just applying LCA and LCC to assess flooring options [78] and the effects of different crops on land use [79].

The main research needs identified by the case study publications were the way of weighting between sustainability dimensions and the integration of all three dimensions, e.g., how to deal with inconsistencies in system boundaries [74,75,77]. Further case studies [40,76,77], and improving data availability, especially for S-LCA [74,77], were additionally identified as potential areas for improvement.

\subsubsection{Methods Not Identified by the Structured Literature Review}

It is worth noting that prominent assessment methods such as eco-efficiency analysis [80], SEEbalance [81,82] or PROSA [83] did not make it into this review, even though they assess two (eco-efficiency analysis) or three (SEEbalance and PROSA) sustainability dimensions. This is a result of the strict search string formulation when the literature search was conducted where no paper on these methods surfaced. This might also indicate another characteristic of the discovered field of papers. As methods from authors with affiliations to companies are hardly present in the analyzed set of publications, it seems that the search for LCSA brought predominantly academic research to light carrying with it a certain view and intended audience. How far this holds true might be an interesting question for further research.

\subsection{Current Status in the Automotive Industry}

Turning to the results of the second step of this research, only Traverso et al. [28] reported in more detail on the integration of LCSA at the BMW Group. While LCA is integrated into product development process and used to identify and quantify measures for the improvement 
of environmental impacts there, work is still to be done on integrating social and economic impact assessment. First steps towards the operationalization of Social LCA have been taken by co-founding the Roundtable for Product Social Metrics, an industry-led initiative that produced a handbook on implementing product social impact assessment [84].

The results of the investigation of other sources regarding the current status of LCSA within the automotive industry are presented in Table 5 where all automobile manufacturers are listed that produced more than one million cars in 2014 [85]. Together, they manufactured more than $85 \%$ of the world's production volume of cars.

It is evident that virtually all of the top 15 car manufacturers employ LCA as life cycle based sustainability assessment. Only two Chinese manufacturers do not seem to apply LCA. Nine of the manufacturers that employ LCA even had their results certified from a third party to use it in their communication. Noteworthy is the clear focus on "just" LCA, meaning the sole addressing of the environmental dimension of product sustainability. An exception is Ford where all three dimensions of sustainability are addressed by additionally assessing the total cost of ownership as well as a few indicators related to the social impact of the use phase of their product. However, the LCA method applied at Ford still adheres to the ISO standard as formulated in 1997. Furthermore, there are singular efforts to address other sustainability dimensions at other OEMs. Research has been carried out at Volkswagen on LCC [14] and a dissertation on S-LCA at Daimler [86].

When looking at how many of the OEMs communicate their results externally, the number shrinks to roughly half. Those who communicated their LCA results publicly focus mainly on greenhouse gas emissions (GHG) while the presentation of the results was done in comparison with the respective predecessor model or a conventional model when assessing alternative drive systems. Another way was to report the absolute results of the indicators.

It can be summarized that (environmental) LCA is well accepted and practiced throughout the world's top car manufacturers, whereas comprehensive Life Cycle Sustainability Assessment of cars cannot be found. Even though Ford is reporting on social and economic criteria in their Product Sustainability Index, they focus rather on the use phase, thus not taking the entire life cycle into account.

As the automotive industry has to prove to legislators that their products do not contain legally banned substances and that they fulfill the required recycling quotas, they have to determine the material balance of their cars [87]. To efficiently manage the information on material composition of the many components that are sourced externally and thus are supplied by several suppliers to several car manufacturers, the International Material Data System (IMDS) was established in which all this information is entered by suppliers and can be extracted from OEMs. 
Table 5. Status of communication on environmental, social and economic aspects of products at the world's top 15 automobile manufacturers of 2014. Information sources were the sustainability reports, product sustainability declarations and websites of the respective companies.

\begin{tabular}{|c|c|c|c|c|c|c|c|}
\hline Rank & Group & Cars & Methods Used & Certification & $\begin{array}{l}\text { Sustainability } \\
\text { Dimensions }\end{array}$ & $\begin{array}{l}\text { Separate Communication of } \\
\text { Product Related Results }\end{array}$ & Details Separate Communication \\
\hline 1 & Volkswagen & $9,766,293$ & LCA & ISO $14040 / 44$ & environmental & $\begin{array}{l}\text { "Umweltprädikat"/ } \\
\text { "Environmental Commendation" }\end{array}$ & $\begin{array}{l}\text { - comparison with predecessor } \\
\text { - life span: } 150,000 \mathrm{~km} \\
\text { - focus on GHG emissions }\end{array}$ \\
\hline 2 & Toyota & $8,788,018$ & LCA & ISO $14040 / 44$ & environmental & $\begin{array}{l}\text { "Environmental Declaration" for } \\
\text { electric vehicles }\end{array}$ & $\begin{array}{l}\text { - comparison with conventional vehicle } \\
\text { - life span: } 150,000 \mathrm{~km} \\
\text { - focus on GHG emissions }\end{array}$ \\
\hline 3 & Hyundai & $7,628,779$ & LCA & ISO 14040/44 & environmental & $\begin{array}{l}\text { communication of GHG over life } \\
\text { cycle for selected models in } \\
\text { sustainability report }\end{array}$ & $\begin{array}{l}\text { - absolute results } \\
\text { - life span: } 120,000 \mathrm{~km} \\
\text { - focus on GHG emissions }\end{array}$ \\
\hline 4 & GM & $6,643,030$ & LCA & - & environmental & - & - \\
\hline 5 & Honda & $4,478,123$ & LCA & - & environmental & - & - \\
\hline 6 & Nissan & $4,279,030$ & LCA & ISO $14040 / 44$ & environmental & $\begin{array}{l}\text { communication of } \mathrm{CO}_{2} \mathrm{e} \\
\text { emissions over life cycle for } \\
\text { selected models in sustainability } \\
\text { report }\end{array}$ & $\begin{array}{l}\text { - comparison with conventional vehicle } \\
\text { - life span: different for } \\
\text { different models } \\
\text { - focus on GHG emissions }\end{array}$ \\
\hline 7 & Ford & $3,230,842$ & $\begin{array}{l}\text { - LCA } \\
\text { - Environmental and } \\
\text { Social indicators } \\
\text { - LCC/Total Cost } \\
\text { of Ownership }\end{array}$ & - & $\begin{array}{l}\text { - environmental } \\
\text { - social } \\
\text { - economic }\end{array}$ & "Product Sustainability Index" & $\begin{array}{l}\text { - absolute results and comparison } \\
\text { with predecessor } \\
\text { - life span: } 150,000 \mathrm{~km} \\
\text { - environmental: focus on GHG and air } \\
\text { emissions, noise, and recycling } \\
\text { - social: safety and space in vehicle } \\
\text { - economic: focus on total cost of } \\
\text { ownership for customer (3 years) }\end{array}$ \\
\hline 8 & Suzuki & $2,543,077$ & LCA & - & environmental & - & - \\
\hline 9 & PSA & $2,521,833$ & LCA & - & environmental & $\begin{array}{l}\text { communication of entire fleet's } \\
\mathrm{CO}_{2} \text { footprint in } \\
\text { sustainability report }\end{array}$ & $\begin{array}{l}\text { - absolute results } \\
\text { - life span: } 150,000 \mathrm{~km} \\
\text { - focus on GHG emissions }\end{array}$ \\
\hline
\end{tabular}


Table 5. Cont.

\begin{tabular}{|c|c|c|c|c|c|c|c|}
\hline Rank & Group & Cars & Methods Used & Certification & $\begin{array}{l}\text { Sustainability } \\
\text { Dimensions }\end{array}$ & $\begin{array}{l}\text { Separate Communication of } \\
\text { Product Related Results }\end{array}$ & Details Separate Communication \\
\hline 10 & Renault & $2,398,555$ & LCA & - & environmental & $\begin{array}{l}\text { communication of LCA results } \\
\text { for electric vehicles }\end{array}$ & $\begin{array}{l}\text { - absolute results and comparison with } \\
\text { conventional vehicle } \\
\text { - life span: 150,000 km } \\
\text { - focus on CML2001 impact categories }\end{array}$ \\
\hline 11 & BMW & $2,165,566$ & LCA & ISO $14040 / 44$ & environmental & $\begin{array}{l}\text { "Umwelterklärung"/ } \\
\text { "Environmental Declaration" } \\
\text { for selected models }\end{array}$ & $\begin{array}{l}\text { - relative results showing distribution } \\
\text { of } \mathrm{CO}_{2} \text { e emissions over life cycle } \\
\text { - life span: } 150,000-250,000 \mathrm{~km} \\
\text { - focus on GHG emissions }\end{array}$ \\
\hline 12 & Fiat & $1,904,618$ & LCA & - & environmental & - & - \\
\hline 13 & Daimler AG & $1,808,125$ & LCA & ISO $14040 / 44$ & environmental & $\begin{array}{l}\text { "Umweltzertifikat"/ } \\
\text { "Environmental Certificate" }\end{array}$ & $\begin{array}{l}\text { - absolute results } \\
\text { - life span: } 160,000-300,000 \mathrm{~km} \\
\text { - focus on CML2001 impact categories }\end{array}$ \\
\hline 14 & SAIC & $1,769,837$ & - & - & - & - & - \\
\hline 15 & Changan & $1,089,179$ & & & \multicolumn{3}{|c|}{ [Only Chinese communication] } \\
\hline \multicolumn{2}{|c|}{ Subtotal Top 15} & $61,014,905$ & & & & & \\
\hline \multicolumn{2}{|c|}{ World Total } & $72,068,994$ & & & & & \\
\hline
\end{tabular}




\subsection{Implications for Application at an Automotive Company}

Looking at the results from both research steps in this paper, it can be surmised that the structured literature analysis provided a view of the state of the art in the field of LCSA highlighting the major areas for research in the identified thematic clusters. Taking those findings and adding the insights gained in the second step of this research on the current status of product sustainability assessment in the automotive industry, the implications for the next steps towards the operationalization of LCSA were derived by consulting with decision makers within an automotive company. In the following, the possible next steps to address these research needs at an automotive company are proposed.

Several challenges for operationalization were identified that hinder the adoption of LCSA at an automotive company. A considerable barrier is the challenge to consistently carry out the three life cycle techniques. Within the thematic field of framework development there were still some unanswered challenges regarding the different maturities of the methods as well as questions regarding the requirement of consistent system boundaries. The systematical prerequisite of applying the same system boundaries is questioned because of the different foci that the individual methods have which could be understood as having no consistent system boundaries. This poses the question how consistent the system boundaries for practical implementation have to be. It can be argued that even the formally consistent formulation of system boundaries will yield emphases on different life cycle phases depending on the method carried out. For instance, even if research and development is an important part of the product life cycle from an economic perspective, it usually has marginal impacts on environment and society [15]. Heijungs et al. [88] understand this as the natural result of three different perspectives on the same object of interest. Decision makers saw the consistency of system barriers as less critical as long as it is ensured that the main impacts in every dimension were identified.

Proposed next step: For operationalization at an automotive company, a case study would be desirable that executes the LCSA with formally consistent boundaries and formats the seemingly inconsistent results in such a way that decision makers can nevertheless arrive at a conclusion.

As already mentioned, the low methodical maturity of S-LCA, notwithstanding the quasi-guidelines by UNEP/SETAC, and the more technical barrier of limited data availability for social impacts pose an additional barrier to implementing S-LCA as part of an LCSA framework at an automotive company as experiences regarding the social assessment of products at the 15 examined OEMs are rather scarce. Decision makers saw an entire S-LCA as too big a challenge for the time being but saw definitive advantage in social risk assessment of supply chains in order to efficiently manage social risks.

Proposed next step: When working towards operationalization of S-LCA, it should be assured that the indicators are relevant for companies operating in the automotive industry. Additionally, the relevancy for the coverage of social topics should match the strategic approach of the company as e.g., defined in their materiality analyses. This would enable linking corporate strategy and product sustainability even more closely. Looking at data availability, there currently are several efforts to build up social databases to address this issue, resorting more often than not to MRIO databases as basis, for instance the Social Hotspot Database or the Product Social Impact Life Cycle Assessment (PSILCA), which enable the simulation of supply chains and thus the building of a life cycle inventory even when limited data are available. A next step towards integration would be the evaluation of these databases and the decision for a mode in which data should be acquired, e.g., hotspot identification via databases and then primary data collection for said hotspots. Important insights might additionally be gained once the dissertation about S-LCA at Daimler is published.

Another methodical challenge not as prominently identified by the structured literature review but strongly emphasized by decision makers was the interpretation of results. As the support for decision makers is the intended goal of an LCSA study, clear and easily understandable results are desired. Therefore, aggregation and/or weighting of results for the different sustainability dimensions are topics that have received some attention with different results calling for further research. 
Proposed next step: For adoption at an automotive company, this will be of crucial importance along with communication formats as the eventual goal of applying LCSA is to enable informed decisions to improve product sustainability. Additionally, the presentation and communication of results is an aspect that harbors the potential of becoming a barrier when done poorly but also being an enabler when used to its full potential. Therefore, it should be investigated whether decision makers need the aggregation of results into one dimension or if other modes of interpretation and communication would also be viable.

Another point strongly emphasized by decision makers was the desire to be able to express sustainability impacts in monetary terms, i.e., costs or revenue for the company, as this would facilitate the interpretation and inclusion of sustainability criteria in management decisions.

Proposed next step: A monetization method for translating product sustainability impacts into monetary units relevant to the company (costs or revenues) should be developed.

Opposite the identified challenges, there was seen potential for the translation of LCSA into practice at an automotive company.

First, the widespread acceptance and proliferation of LCA across the majority of top car manufacturers, as discovered in the second step of this research, shows that life cycle thinking and assessment of sustainability impacts is not foreign to the industry. Thus, the introduction of a life cycle based assessment framework that adds two more dimensions to the existing environmental dimension should, on the account of "understanding of the method", not be a hindrance. Decision makers understood and generally supported the combined assessment and management of environmental and social aspects of a product's life cycle.

Additionally, the automotive industry keeps track of components that are built into their cars and the materials they are composed of with the help of the International Material Data System (IMDS). Based on this system with the additional information on in-house production, all materials that are incorporated in a car can be accounted for and thus data gathering for the building of the physical life cycle inventory is facilitated.

Proposed next steps: At several OEMs, inter alia BMW, Daimler, and VW, information from the IMDS is already used for doing LCA. For prospectively using it to also conduct S-LCA, the expansion of information gathered with this system should be expanded to at least also contain information about the origins of materials and components.

\subsection{Limitations}

First and foremost, the search for literature on only four distinct sources and the stringent definition of the search term in order to narrow down the amount of initial hits pose as sources for uncertainty in the final set of relevant publications as important contributions could have been overlooked due to a too narrow search focus. Likewise, the exclusion of publications that addressed only one sustainability dimension can have an impact on the picture that this research yielded for the state of the art of LCSA as works that address advances of singular methods that are nevertheless part of LCSA did not find their way into the final assessment.

\section{Conclusions}

The aim of this paper was to identify challenges and potential for implementing Life Cycle Sustainability Assessment (LCSA) at an automotive company. The identified research needs regarding LCSA and the resulting next steps towards operationalization of LCSA at an automotive company were:

\section{Consistent execution of the three life cycle based assessment methods}

- $\quad$ Conduct case study to determine the best handling of the question around consistent system boundaries, especially whether a consistent picture of the results is needed.

\section{Comparatively low maturity of S-LCA}


- $\quad$ Ensure consistency of social topics with company specific strategy.

- $\quad$ Evaluate currently available databases and decide on a mode of data acquisition.

\section{Presentation and interpretation of results}

- $\quad$ Regarding aggregation of sustainability dimensions, it should be determined what weights decision makers would assign to the individual sustainability criteria or dimensions.

- A way of monetizing sustainability impacts should be developed to support decision makers in interpreting the results.

- A communication format should be devised that easily and clearly conveys the LCSA results and is directed at the relevant decision makers.

Most of these steps would ideally be taken by carrying out a case study at an automotive company after methodical questions, e.g., indicators for S-LCA, data acquisition mode, and way of aggregation, have been addressed. The proliferation of LCA within the automotive industry and the IMDS as common data acquisition system can facilitate the operationalization.

Supplementary Materials: The following are available online at www.mdpi.com/2071-1050/9/4/670/s1.

Acknowledgments: This paper is part of a cumulative PhD thesis sponsored by BMW.

Author Contributions: Peter Tarne is the first and main author of the article. The research including literature survey and analysis was carried out by him. Marzia Traverso and Matthias Finkbeiner provided the overall research idea and contributed to the research design of the study. All authors contributed to writing, revising, proofreading and approving the final manuscript.

Conflicts of Interest: The authors declare no conflict of interest.

\section{References and Notes}

1. JRC. Towards a Life-Cycle Based European Sustainability Footprint Framework; Pelletier, N., Maas, R., Goralcyk, M., Wolf, M.-A., Eds.; Publications Office of the European Union: Luxembourg, 2012.

2. Singh, R.K.; Murty, H.R.; Gupta, S.K.; Dikshit, A.K. An overview of sustainability assessment methodologies. Ecol. Indic. 2009, 15, 281-299. [CrossRef]

3. UNEP/SETAC Life Cycle Initiative. Towards a Life Cycle Sustainability Assessment-Making Informed Choices on Products; Valdivia, S., Ugaya, C.M.L., Sonnemann, G., Hildenbrand, J., Eds.; UNEP/SETAC Life Cycle Initiative: Paris, France, 2011.

4. Klöpffer, W. Life-Cycle based methods for sustainable product development. Int. J. Life Cycle Assess. 2003, 8, 157-159. [CrossRef]

5. Klöpffer, W. Life cycle sustainability assessment of products. Int. J. Life Cycle Assess. 2008, 13, 89-95. [CrossRef]

6. Finkbeiner, M.; Reimann, K.; Ackermann, R. Life cycle sustainability assessment (LCSA) for products and processes. In Proceedings of the SETAC Europe 18th Annual Meeting, Warsaw, Poland, 25-29 May 2008.

7. Finkbeiner, M.; Schau, E.M.; Lehmann, A.; Traverso, M. Towards Life Cycle Sustainability Assessment. Sustainability 2010, 2, 3309-3322. [CrossRef]

8. Ness, B.; Urbel-Piirsalu, E.; Anderberg, S.; Olsson, L. Categorising tools for sustainability assessment. Ecol. Econ. 2007, 60, 498-508. [CrossRef]

9. Zamagni, A. Life cycle sustainability assessment. Int. J. Life Cycle Assess. 2012, 17, 373-376. [CrossRef]

10. ISO 14040. DIN EN ISO 14040: Umweltmanagement-Ökobilanz-Grundsätze und Rahmenbedingungen; ISO: Geneva, Switzerland, 2006.

11. ISO 14044. DIN EN ISO 14044: Umweltmanagement-Ökobilanz-Anforderungen und Anleitungen; ISO: Geneva, Switzerland, 2006.

12. UNEP/SETAC. Guidelines for Social Life Cycle Assessment of Products; UNEP/Earthprint: Nairobi, Kenya, 2009.

13. Dreyer, L. Inclusion of Social Aspects in Life Cycle Assessment of Products. Ph.D.Thesis, Technical University of Denmark, Copenhagen, Danemark, 2009. 
14. Bubeck, D. Life Cycle Costing (LCC) im Automobilbau: Analyse und Planung von Lebenszykluskosten bei der Entwicklung von Produkten und Produktsystemen. Ansatz zur Integration des LCC Innerhalb der Ganzheitlichen Bilanzierung, 1st ed.; Quantitative Methoden in Forschung und Praxis; Kovač: Hamburg, Germany, 2002.

15. Swarr, T.E.; Hunkeler, D.; Klöpffer, W.; Hanna-Leena, P.; Ciroth, A.; Brent, A.C.; Pagan, R. Environmental Life Cycle Costing: A Code of Practice. Int. J. Life Cycle Assess. 2011, 16, 389-391. [CrossRef]

16. WCED. Report of the World Commission on Enviroment and Development: Our Common Future; UN: New York, NY, USA, 1987.

17. Sala, S.; Farioli, F.; Zamagni, A. Life cycle sustainability assessment in the context of sustainability science progress (part 2). Int. J. Life Cycle Assess. 2013, 18, 1686-1697. [CrossRef]

18. Tranfield, D.; Denyer, D.; Smart, P. Towards a Methodology for Developing Evidence-Informed Management Knowledge by Means of Systematic Review. Br. J. Manag. 2003, 14, 207-222. [CrossRef]

19. Pickering, C.; Byrne, J. The benefits of publishing systematic quantitative literature reviews for PhD candidates and other early-career researchers. High. Educ. Res. Dev. 2014, 33, 534-548. [CrossRef]

20. Jasinski, D.; Meredith, J.; Kirwan, K. A comprehensive review of full cost accounting methods and their applicability to the automotive industry. J. Clean. Prod. 2015, 108, 1123-1139. [CrossRef]

21. Duff, A. The literature search: A library-based model for information skills instruction. Libr. Rev. 1996, 45, 14-18. [CrossRef]

22. Randolph, J. A Guide to Writing the Dissertation Literature Review. Pract. Assess. Res. Eval. 2009, 14, 1-13.

23. Petticrew, M.; Roberts, H. Systematic Reviews in the Social Sciences-A Practical Guide; Blackwell Publishing Ltd.: Oxford, UK, 2006.

24. Mattioda, R.A.; Mazzi, A.; Canciglieri, O.; Scipioni, A. Determining the principal references of the social life cycle assessment of products. Int. J. Life Cycle Assess. 2015, 20, 1155-1165. [CrossRef]

25. Zimmer, K.; Fröhling, M.; Schultmann, F. Sustainable supplier management-A review of models supporting sustainable supplier selection, monitoring and development. Int. J. Prod. Res. 2016, 54, 1412-1442. [CrossRef]

26. Miemczyk, J.; Johnsen, T.E.; Macquet, M. Sustainable purchasing and supply management: A structured literature review of definitions and measures at the dyad, chain and network levels. Supply Chain Manag. Int. J. 2012, 17, 478-496. [CrossRef]

27. Wacker, J. A definition of theory: Research guidelines for different theory-building research methods in operations management. J. Oper. Manag. 1998, 16, 361-385. [CrossRef]

28. Traverso, M.; Kim, P.; Brattig, S.; Wagner, V. Managing Life Cycle Sustainability Aspects in the Automotive Industry; Springer: Berlin, Germany, 2015; pp. 331-339.

29. Igarashi, M.; de Boer, L.; Fet, A.M. What is required for greener supplier selection? A literature review and conceptual model development. J. Purch. Supply Manag. 2013, 19, 247-263. [CrossRef]

30. Edmondson, A.C.; McManus, S.E. Methodological Fit in Management Field Research. Acad. Manag. Rev. 2007, 32, 1155-1179. [CrossRef]

31. Traverso, M.; Asdrubali, F.; Francia, A.; Finkbeiner, M. Towards life cycle sustainability assessment: An implementation to photovoltaic modules. Int. J. Life Cycle Assess. 2012, 17, 1068-1079. [CrossRef]

32. Traverso, M.; Finkbeiner, M.; Jørgensen, A.; Schneider, L. Life Cycle Sustainability Dashboard. J. Ind. Ecol. 2012, 16, 680-688. [CrossRef]

33. Sala, S.; Farioli, F.; Zamagni, A. Progress in sustainability science: Lessons learnt from current methodologies for sustainability assessment: Part 1. Int. J. Life Cycle Assess. 2013, 18, 1653-1672. [CrossRef]

34. Hoogmartens, R.; Van Passel, S.; Van Acker, K.; Dubois, M. Bridging the gap between LCA, LCC and CBA as sustainability assessment tools. Environ. Impact Assess. Rev. 2014, 48, 27-33. [CrossRef]

35. Klöpffer, W.; Grahl, B. From LCA to Sustainability Assessment. In Life Cycle Assessment (LCA); Wiley-VCH Verlag GmbH \& Co. KGaA: Weinheim, Germany, 2014; pp. 357-374.

36. Jørgensen, A.; Herrmann, I.T.; Bjørn, A. Analysis of the link between a definition of sustainability and the life cycle methodologies. Int. J. Life Cycle Assess. 2013, 18, 1440-1449. [CrossRef]

37. Keller, H.; Rettenmaier, N.; Reinhardt, G.A. Integrated life cycle sustainability assessment-A practical approach applied to biorefineries. Appl. Energy 2015, 154, 1072-1081. [CrossRef]

38. Neugebauer, S.; Martinez-Blanco, J.; Scheumann, R.; Finkbeiner, M. Enhancing the practical implementation of life cycle sustainability assessment-proposal of a Tiered approach. J. Clean. Prod. 2015, 102, 165-176. [CrossRef] 
39. Cinelli, M.; Coles, S.R.; Jørgensen, A.; Zamagni, A.; Fernando, C.; Kirwan, K. Workshop on life cycle sustainability assessment: The state of the art and research needs-November 26, 2012, Copenhagen, Denmark. Int. J. Life Cycle Assess. 2013, 18, 1421-1424. [CrossRef]

40. Valdivia, S.; Ugaya, C.M.L.; Hildenbrand, J.; Traverso, M.; Mazijn, B.; Sonnemann, G. A UNEP/SETAC approach towards a life cycle sustainability assessment-our contribution to Rio + 20. Int. J. Life Cycle Assess. 2013, 18, 1673-1685. [CrossRef]

41. Hu, M.; Kleijn, R.; Bozhilova-Kisheva, K.P.; Di Maio, F. An approach to LCSA: The case of concrete recycling. Int. J. Life Cycle Assess. 2013, 18, 1793-1803. [CrossRef]

42. Stefanova, M.; Tripepi, C.; Zamagni, A.; Masoni, P. Goal and Scope in Life Cycle Sustainability Analysis: The Case of Hydrogen Production from Biomass. Sustainability 2014, 6, 5463-5475. [CrossRef]

43. Pesonen, H.-L.; Horn, S. Evaluating the Sustainability SWOT as a streamlined tool for life cycle sustainability assessment. Int. J. Life Cycle Assess. 2013, 18, 1780-1792. [CrossRef]

44. Foolmaun, R.K.; Ramjeawon, T. Life cycle sustainability assessments (LCSA) of four disposal scenarios for used polyethylene terephthalate (PET) bottles in Mauritius. Environ. Dev. Sustain. 2013, 15, 783-806. [CrossRef]

45. Foolmaun, R.K.; Ramjeeawon, T. Comparative life cycle assessment and social life cycle assessment of used polyethylene terephthalate (PET) bottles in Mauritius. Int. J. Life Cycle Assess. 2013, 18, 155-171. [CrossRef]

46. Vinyes, E.; Oliver-Solà, J.; Ugaya, C.; Rieradevall, J.; Gasol, C.M. Application of LCSA to used cooking oil waste management. Int. J. Life Cycle Assess. 2013, 18, 445-455. [CrossRef]

47. Souza, R.G.; Rosenhead, J.; Salhofer, S.P.; Valle, R.A.B.; Lins, M.P.E. Definition of sustainability impact categories based on stakeholder perspectives. J. Clean. Prod. 2015, 105, 41-51. [CrossRef]

48. Manzardo, A.; Ren, J.; Mazzi, A.; Scipioni, A. A grey-based group decision-making methodology for the selection of hydrogen technologies in life cycle sustainability perspective. Int. J. Hydrog. Energy 2012, 37, 17663-17670. [CrossRef]

49. Ghadimi, P.; Azadnia, A.H.; Mohd Yusof, N.; Mat Saman, M.Z. A weighted fuzzy approach for product sustainability assessment: A case study in automotive industry. J. Clean. Prod. 2012, 33, 10-21. [CrossRef]

50. Wang, X.; Chan, H.K. An integrated fuzzy approach for evaluating remanufacturing alternatives of a product design. J. Remanuf. 2013, 3, 10. [CrossRef]

51. Ren, J.; Manzardo, A.; Mazzi, A.; Zuliani, F.; Scipioni, A. Prioritization of bioethanol production pathways in China based on life cycle sustainability assessment and multicriteria decision-making. Int. J. Life Cycle Assess. 2015, 20, 842-853. [CrossRef]

52. Buchert, T.; Neugebauer, S.; Schenker, S.; Lindow, K.; Stark, R. Multi-criteria Decision Making as a Tool for Sustainable Product Development-Benefits and Obstacles. Procedia CIRP 2015, 26, 70-75. [CrossRef]

53. Halog, A.; Manik, Y. Advancing Integrated Systems Modelling Framework for Life Cycle Sustainability Assessment. Sustainability 2011, 3, 469-499. [CrossRef]

54. Ostermeyer, Y.; Wallbaum, H.; Reuter, F. Multidimensional Pareto optimization as an approach for site-specific building refurbishment solutions applicable for life cycle sustainability assessment. Int. J. Life Cycle Assess. 2013, 18, 1762-1779. [CrossRef]

55. Bachmann, T.M. Towards life cycle sustainability assessment: Drawing on the NEEDS project's total cost and multi-criteria decision analysis ranking methods. Int. J. Life Cycle Assess. 2013, 18, 1698-1709. [CrossRef]

56. Kucukvar, M.; Tatari, O. Towards a triple bottom-line sustainability assessment of the U.S. construction industry. Int. J. Life Cycle Assess. 2013, 18, 958-972. [CrossRef]

57. Onat, N.; Kucukvar, M.; Tatari, O. Integrating triple bottom line input-output analysis into life cycle sustainability assessment framework: The case for US buildings. Int. J. Life Cycle Assess. 2014, 19, 1488-1505. [CrossRef]

58. Onat, N.; Kucukvar, M.; Tatari, O. Towards Life Cycle Sustainability Assessment of Alternative Passenger Vehicles. Sustainability 2014, 6, 9305-9342. [CrossRef]

59. Kucukvar, M.; Noori, M.; Egilmez, G.; Tatari, O. Stochastic decision modeling for sustainable pavement designs. Int. J. Life Cycle Assess. 2014, 19, 1185-1199. [CrossRef]

60. Schulz, M.; Short, M.D.; Peters, G.M. A streamlined sustainability assessment tool for improved decision making in the urban water industry. Integr. Environ. Assess. Manag. 2012, 8, 183-193. [CrossRef] [PubMed]

61. Nzila, C.; Dewulf, J.; Spanjers, H.; Tuigong, D.; Kiriamiti, H.; van Langenhove, H. Multi criteria sustainability assessment of biogas production in Kenya. Appl. Energy 2012, 93, 496-506. [CrossRef] 
62. Luthe, T.; Kägi, T.; Reger, J. A Systems Approach to Sustainable Technical Product Design. J. Ind. Ecol. 2013, 17, 605-617. [CrossRef]

63. Mjörnell, K.; Boss, A.; Lindahl, M.; Molnar, S. A Tool to Evaluate Different Renovation Alternatives with Regard to Sustainability. Sustainability 2014, 6, 4227-4245. [CrossRef]

64. Stamford, L.; Azapagic, A. Life cycle sustainability assessment of electricity options for the UK. Int. J. Energy Res. 2012, 36, 1263-1290. [CrossRef]

65. Stamford, L.; Azapagic, A. Life cycle sustainability assessment of UK electricity scenarios to 2070. Energy Sustain. Dev. 2014, 23, 194-211. [CrossRef]

66. Dewulf, J.; Mancini, L.; Blengini, G.A.; Sala, S.; Latunussa, C.; Pennington, D. Toward an Overall Analytical Framework for the Integrated Sustainability Assessment of the Production and Supply of Raw Materials and Primary Energy Carriers. J. Ind. Ecol. 2015, 19, 963-977. [CrossRef]

67. Hirschberg, S.; Burgherr, P. Sustainability Assessment for Energy Technologies. In Handbook of Clean Energy Systems; John Wiley \& Sons, Ltd.: Hoboken, NJ, USA, 2015; pp. 1-22.

68. Moriizumi, Y.; Matsui, N.; Hondo, H. Simplified life cycle sustainability assessment of mangrove management: A case of plantation on wastelands in Thailand. J. Clean. Prod. 2010, 18, 1629-1638. [CrossRef]

69. Zhou, Z.; Jiang, H.; Qin, L. Life cycle sustainability assessment of fuels. Fuel 2007, 86, 256-263. [CrossRef]

70. Ingwersen, W.; Cabezas, H.; Weisbrod, A.; Eason, T.; Demeke, B.; Ma, X.; Hawkins, T.R.; Lee, S.-J.; Bare, J.; Ceja, M. Integrated Metrics for Improving the Life Cycle Approach to Assessing Product System Sustainability. Sustainability 2014, 6, 1386-1413. [CrossRef]

71. Li, H.; Nitivattananon, V.; Li, P. Developing a Sustainability Assessment Model to Analyze China's Municipal Solid Waste Management Enhancement Strategy. Sustainability 2015, 7, 1116-1141. [CrossRef]

72. Azapagic, A.; Stichnothe, H. Life cycle sustainability assessment of biofuels. In Handbook of Biofuels Production; Luque, R., Ed.; Woodhead Publishing Ltd.: Cambridge, UK, 2010; pp. 37-60.

73. Jeswani, H.K.; Azapagic, A. Life cycle sustainability assessment of second generation biodiesel. In Advances in Biodiesel Production; Woodhead Publishing Ltd.: Cambridge, UK, 2012; pp. 13-31.

74. Schau, E.M.; Traverso, M.; Finkbeiner, M. Life cycle approach to sustainability assessment: A case study of remanufactured alternators. J. Remanuf. 2012, 2, 5. [CrossRef]

75. Lu, B.; Li, B.; Wang, L.; Yang, J.; Liu, J.; Wang, X.V. Reusability based on Life Cycle Sustainability Assessment: Case Study on WEEE. Procedia CIRP 2014, 15, 473-478. [CrossRef]

76. Yu, M.; Halog, A. Solar Photovoltaic Development in Australia-A Life Cycle Sustainability Assessment Study. Sustainability 2015, 7, 1213-1247. [CrossRef]

77. Martínez-Blanco, J.; Lehmann, A.; Muñoz, P.; Antón, A.; Traverso, M.; Rieradevall, J.; Finkbeiner, M. Application challenges for the social Life Cycle Assessment of fertilizers within life cycle sustainability assessment. J. Clean. Prod. 2014, 69, 34-48. [CrossRef]

78. Minne, E.; Crittenden, J.C. Impact of maintenance on life cycle impact and cost assessment for residential flooring options. Int. J. Life Cycle Assess. 2015, 20, 36-45. [CrossRef]

79. Brandão, M.; Clift, R.; Canals, L.M.; Basson, L. A Life-Cycle Approach to Characterising Environmental and Economic Impacts of Multifunctional Land-Use Systems: An Integrated Assessment in the UK. Sustainability 2010, 2, 3747-3776. [CrossRef]

80. Saling, P.; Kicherer, A.; Dittrich-Krämer, B.; Wittlinger, R.; Zombik, W.; Schmidt, I.; Schrott, W.; Schmidt, S. Eco-efficiency analysis by basf: The method. Int. J. Life Cycle Assess. 2002, 7, 203-218. [CrossRef]

81. Schmidt, I.; Meurer, M.; Saling, P.; Kicherer, A.; Reuter, W.; Gensch, C.-O. SEEbalance. Green. Manag. Int. 2004, 2004, 78-94. [CrossRef]

82. Saling, P.; Maisch, R.; Silvani, M.; König, N. Assessing the Environmental-Hazard Potential for Life Cycle Assessment, Eco-Efficiency and SEEbalance (8 pp). Int. J. Life Cycle Assess. 2005, 10, 364-371. [CrossRef]

83. Grießhammer, R.; Buchert, M.; Gensch, C.; Hochfeld, C.; Manhart, A.; Rüdenauer, I.; Ebinger, F. PROSA_Product Sustainability Assessment; Öko-Institut e.V.: Berlin, Germany, 2007.

84. Fontes, J.; Bolhuis, A.; Bogaers, K.; Saling, P.; van Gelder, R.; Traverso, M.; Das Gupta, J.; Morris, D.; Bosch, H.; Woodyard, D.; et al. Handbook for Product Social Impact Assessment, 2nd ed.; PRé Sustainability: Amersfoot, Holland, 2015.

85. OICA. Production Statistics 2014. Available online: http://www.oica.net/category/production-statistics / 2014-statistics / (accessed on 15.08.2015). 
86. Karlewski, H. Social Life Cycle Assessment in the Automotive Industry. Doctoral Thesis, Technische Universität Berlin, Berlin, German, 2016.

87. European Commission Directive 2000/53/EC on end-of life vehicles. Off. J. Eur. Communities 2000, L 269, $1-15$.

88. Heijungs, R.; Huppes, G.; Guinée, J.B. A Scientific Framework for LCA; Institute of Enviromental Science, Leiden Unversity: Leiden, The Netherlands, 2009.

(c) (

(C) 2017 by the authors. Licensee MDPI, Basel, Switzerland. This article is an open access article distributed under the terms and conditions of the Creative Commons Attribution (CC BY) license (http:/ / creativecommons.org/licenses/by/4.0/). 